Ministerstwo Nauki

i Szkolnictwa Wyższego

Digitalizacja archiwalnych numerów czasopisma naukowego Analecta Cracoviensia 1-24 (1969-1992)

i ich publikacja w otwartym dostępie - zadanie finansowane w ramach umowy 672/P-DUN/2017 ze środków

Ministra Nauki i Szkolnictwa Wyższego przeznaczonych na działalność upowszechniającą naukę

\title{
POWSTANIE KANONICZNEJ KONCEPCJI WARUNKOWEGO ZAWARCIA MAEŻEŃSTWA
}

\section{ZAGADNIENIA WPROWADZAJĄCE}

Zawarcie małżeństwa pod warunkiem stwarza dla niejednego autora problem niezwykle trudny ze względu na odmienność pojęcia aktu warunkowego stosowanego w tym wypadku w kanonistyce, w porównaniu z pojęciem aktu warunkowego używanym powszechnie w prawie cywilnym, a uprzednio w prawie rzymskim. Jeśli chodzi o wspomnianą różnicę pojęć, to rzeczą zrozumiałą jest, że nie należy porównywać kanonicznego zawarcia mał̇eństwa pod warunkiem z odnośnymi pojęciami Kodeksu Rodzinnego i Opiekuńczego, względnie rzymskiego prawa małżeńskiego, poniewaz obydwa te prawodawstwa nie przyjmują małzeństw warunkowych. Porównanie takie można jedynie przeprowadzić zestawiając wspomniane kanoniczne pojęcie aktu warunkowego z pojęciami Kodeksu Cywilnego ${ }^{1}$, prawa rzymskiego, względnie nauką prawa dotyczącą tych dziedzin. Można zatem postawić pytanie: skąd, kiedy i dlaczego wytworzyło się odmienne pojęcie aktu warunkowego w wypadku małżeństwa pomimo, że w odniesieniu do kontraktów w oparciu o kan. 1529 nadal stosuje się w kanonistyce pojęcie zaczerpnięte z prawa cywilnego.

Ażeby odpowiedzieć na to pytanie, wypada nie tylko porównać pojęcie aktualnie używane w prawie cywilnym i przy zawieraniu małzeństwa kanonicznego, ale ponadto należy cofnąć się wstecz do prawa rzymskiego, a nawet - do prawa żydowskiego. W ten sposób poprzez odpowiednie porównania i przeanalizowanie odnośnych dokumentów prawnych i doktryny dekretystów i dekretalistów można dojść do podstaw odmiennego pojecia aktu warunkowego, a tym samym do uzyskania odpowiedzi na postawione pytanie.

1 Ustawa z dnia 23 kwietnia 1964 r. (Dz. U. nr 16, poz. 93). 


\section{Różnice pojęciowe}

W komentarzu do części ogólnej prawa cywilnego Aleksander Wolter taką podaje definicję warunku: „Przez warunek w sensie technicznym rozumie się zastrzeżenie, mocą którego strona dokonująca czynności prawnej uzależnia powstanie lub ustanie skutku prawnego od zdarzenia przyszłego i niepewnego (art. $89 \mathrm{kc}$ ); niekiedy warunkiem nazywa się również to zdarzenie" ${ }^{2}$. Seweryn Szer w ten sposób określa pojęcie warunku: „Warunkiem nazywamy tego rodzaju postanowienie w treści czynności prawnej, które uzależnia powstanie lub ustanie s k u tków czynności prawnej od zdarzenia przyszłego i niepewnego" "3. Mieczysław Piekarski w komentarzu do Kodeksu Cywilnego na str. 224 taką podaje definicję: „Przez warunek rozumie się oświadczenie woli, mocą którego strona dokonująca czynności prawnych uzależnia p o w s t anie lub ustanie skutków czynności prawnejod zdarzenia przyszłego i niepewnego. Warunek jest istotną częścią składową owej czynności prawnej" " Chociaż w powyższych trzech określeniach warunku są pewne drobne warianty, jednakże, jeśli chodzi o element istotny dla naszego zagadnienia, zgadzają się wszyscy i podają go prawie w identycznym brzmieniu. Chodzi mianowicie tutaj o uzależnienie powstania lub ustania skutków prawnych od zdarzenia przyszłego i niepewnego.

Pod tym względem pojęcia współczesnego prawa cywilnego niewiele odbiegają od dawnych pojęć rzymskich, ponieważ warunek w prawie rzymskim określano, jak podaje Stanisław Wróblewski, jako dodatek modyfikujący skutki prawne: „Warunek to dodatek, w którym strony oświadczają, iż skuteczność czynności prawnej ma być zależna od przyszłego wątpliwego zdarzenia: także to zdarzenie, które ma rozstrzygnąć o skuteczności oznacza się w stosunku do czynności prawnej nazwą warunku" 5. Warto tutaj zaznaczyć, że jest to pojęcie bardzo stare, albowiem już w prawie XII Tablic znana była instytucja warunkowego wyzwolenia testamentowego ${ }^{6}$.

W prawie kanonicznym natomiast pojęcie warunku w wyżej wspomnianym wypadku jest odmienne. Kan $1092.3^{\circ}$ mówi, że warunek godziwy, odnoszący się do przyszłości zawiesza ważność małżeństwa. Nie jest tu uwzględniona jedynie skuteczność, lecz ważność a ktu prawnego, czyli jego istnienie. Stefan Biskupski w swoim pod-

2 Wolter A., Prawo cywilne - Zarys części ogólnej, Warszawa 1967, 265.

3 Szer S., Prawo cywilne - część ogólna, Warszawa 1967, 349.

4 Dzieło zbiorowe: Kodeks Cywilny, komentarz, t. I, art. 56 - 109 opracował Mieczysław Piekarski, Warszawa 1972, 224.

5 Wróblewski St., Zarys wykładu prawa rzymskiego, Kraków 1916, s. 382, nr 142.

6 Tamże, s. 382, nr 149. 
ręczniku prawa małżeńskiego podaje określenie Gasparriego, które brzmi następująco: warunek określa się ,,jako okoliczność dorzuconą, o d k tórej zawisło działanie prawne. Warunki zwykliśmy wypowiadać najczęściej przez partykuły: jeśli, byle, o ile" itp.7.

Jeszcze wyraźniej precyzuje uzależnienie ważności aktu od spełnienia się warunku Capello w swym traktacie kanoniczno-moralnym o sakramentach w t. V dotyczącym sakramentu małżeństwa ${ }^{8}$ : ,Warunek jest okolicznością dodaną do aktu, od którejzależy jego w a ż ność".

Ze względu na nie dość ścisłe uświadomienie sobie wartości danego określenia wielu autorów zamiennie używa słów, od których zależy skuteczność, względnie ważność aktu. Nie zdają sobie sprawy, że chodzi tutaj o bardzo ważną różnicę merytoryczną. Kanoniści najczęściej rozumieją nieskuteczność również w sensie nieważności ${ }^{9}$, a cywiliści konsekwencję postawionego warunku przyjmują w utartym znaczeniu rzymsko-cywilnym. Jest to powodem licznych niedomówień i nieporozumień tym bardziej, że cywiliści nie zawsze jednakowo podchodzą do tego problemu, jak świadczy tekst Aleksandra Woltera zamieszczony w przypisku ${ }^{10}$.

7 Biskupski - Żurowski, Prawo matżeńskie Kościoła rzymskokatolickiego, Warszawa 1971, II, s. $55 \mathrm{nr}$ 406. Por. Gasparri P., Tractatus canonicus de matrimonio I, s. $56 \mathrm{nr}$ 79: "Conditio, ut ab ea incipiamus, in re nostra optime definitur: circumstantia actui" (promissioni) adiecta ex qua ipse actus pendet, idest suspenditur, vel revocatur. Exprimi solet per particulas si, dummodo, modo, et interdum ablativo absoluto, sed hoc non est perpetuum: nam si ea exprimuntur quae actui tacite insunt, verius non conditio intelligitur, sed magis monitio quaedam, quae nihil mutat, quippe eadem est vis taciti et expressi".

8 ,Conditio est circumstantia actui adiecta ex qua eius valor pendet", Cappello

F. M.," Tractatus canonico moralis de sacramentis, Romae 1961, s. $558 \mathrm{nr} 625$.

9 Np.: Cappello, dz. cyt., tamże.

10 ,Dopóki warunek się nie ziści, istnieje stan zawieszenia: strony są związane czynnością prawną i muszą się powstrzymać od działań, które by naruszały prawa strony uprawnionej na wy padek ziszczenia się warunku (np. ten, który sprzedał rzecz pod warunkiem zawieszającym, nie może tej rzeczy uszkadzać lub niszczyé). Warunkowo uprawniony może dokonywać wszelkich czynności zmierzających do zachowania jego praw (art. $91 \mathrm{k}$. c.).

Jak już o tym była mowa w rozdziale IV $\S 4$, prawo warunkowe jest pod niektórymi względami traktowane jak istniejące prawo majątkowe; można nim rozporządzać, przechodzi na spad. kobierców, może być zabezpieczone hipoteką (art. 193 § 2 pr. rzecz.) lub zastawem (art. $306 \S 2 \mathrm{k}$. c.). W innych hipotezach prawo warunkowe nie ma tej samej mocy co prawo bezwarunkowe (np. dłużnik, który zapłacił dług warunkowy przed ziszczeniem się warunku, może żądać zwrotu świadczenia, argument a contrario z art. 411 pkt. 4 k. c.).

$\mathrm{Z}$ chwilą ziszczenia się warunku zawieszającego skutek prawny następuje (np. w razie przeniesienia własności rzeczy ruchomej pod warunkiem zapłaty ceny kupna nabywca staje się właścicielem z momentem zapłaty), z chwilą ziszczenia się warunku rozwiązującego - skutek prawny ustaje (np. nabywca własności rzeczy ruchomej pod warunkiem rozwiązującym przestaje być właścicielem z chwilą ziszczenia się warunku).

Jeżeli pendente conditione dokonane zostało rozporządzenie prawem warunkowym, rozporządzenie to traci moc $\mathrm{z}$ chwilą ziszczenia się warunku o tyle, o ile udaremnia lub ogranicza skutek ziszczenia się warunku, ch y ba ż e n a podstawie takiego rozporządzenia osoba trzecia nabywa prawo 
Cofając się do źródeł nauki prawa o warunkach, już u prawników rzymskich możemy znaleźć różnicę poglądów co do następstw aktu warunkowego np. warunku rozwiązującego, szczególnie od Juliana ${ }^{11}$. Na uwagę zasługuje tzw. negotium purum, stanowiące pierwszą część aktu prawnego i wolną niejako od warunku. Druga część dopiero wywołuje skutki prawne w zależności od spełnienia się zdarzenia niepewnego. Pomimo przytoczenia niektórych różnic zarówno dawni jak i współcześni frawnicy są zgodni, że w prawie cywilnym współczesnym i w prawie rzymskim jest zawsze mowa o takiej czy innej, ale zawsze sk uteczności aktu prawnego, co zdaniem autorów nie pokrywa się znaczeniowo z ważnością aktu.

lub zostaje zwolniona od obowiązku, gdyż wówczas stosuje się odpowiednio przepisy o ochronie osób, które $w$ dobrej wierze dokonały czynności prawnej $\mathrm{z}$ osobą nieuprawnioną do rozporządzania prawem (art. 92 k. c. - np. zbywca rzeczy ruchomej pod warunkiem zawieszającym przed ziszczeniem się warunku zbył ponownie rzecz osobie trzeciej; jeżeli nie wejdzie w zastosowanie przepis art. $169 \mathrm{k}$. c. o nabyciu własności od osoby nieuprawnionej do rozporządzania, osoba trzecia z chwilą ziszczenia się warunku traci własność rzeczy).

Skutki ziszczenia się warunku w braku odmiennego zastrzeżenia następują ex nunc, czyli od chwili ziszczenia się warunku, a nie od chwili dokonania czynności prawnej (art. $90 \mathrm{k}$. c. - np. W razie przeniesienia własności rzeczy ruchomej pod warunkiem zawieszającym zbywca ma prawo zatrzymać pożytki rzeczy, które pobrał pendente conditione).

W celu ochrony zasad współżycia społecznego art. 93 k. c. przewiduje w pewnych wypadkach fikcję ziszczenia się lub nieziszczenia się warunku; jeżeli strona, której zależy na nieziszczeniu się warunku, przeszkodzi w sposób sprzeczny z zasadami współżycia społecznego ziszczeniu się warunku, następuja skutki takie, jak gdyby warunek się ziścił (np. A przyrzeka osobie B premię pod warunkiem wykonania oznaczonej czynności i następnie rozmyślnie udaremnia możliwość jej wykonania); jeżeli strona, której zależy na ziszczeniu się warunku, doprowadzi w sposób sprzeczny z zasadami współżycia społecznego do jego ziszczenia się, następują skutki takie, jak gdyby warunek się nie ziścił.

Jeżeli nie ziścił się warunek zawieszający, skutek prawny w ogóle nie powstaje, jeżeli nie ziścił się warunek rozwiązujący - skutek jest taki, jak gdyby czynność od samego początku była czynnością bezwarunkową." Wolter A., dz. cyt., 267-268. NB. podkreślenia moje.

${ }_{11}$,Ze stanowiska logiki nic nie stoi na przeszkodzie pojmowaniu warunku rozwiązującego jako innej stylizacji warunku zawieszającego: kupno, które ma stracić skuteczność, skoro się znajdzie lepszy kupiec, można traktować jako kupno skutkujące dopiero wówczas, jeżeli się w naznaczonym terminie lepszy kupiec nie trafi, a ślady tego sposobu pojmowania są w źródłach zupełnie wyraźne. Całkowite zrównanie skutków nie odpowiada jednak niewątpliwie woli kontrahentów: jeśli przy takim interesie kupujący zapłacił przed terminem cene, trudno mu pendente condicione przyznać prawo do zwrotu, a jeśli uzyskał posiadanie towaru, trudno mu odmawiać tytułu i wykluczać bieg zasiedzenia przed upływem terminu, skoro w terminie nie było lepszej oferty i kupno według intencji stron skuteczności nie utraciło. Odmiennemu nastrojowi woli można było zadośćuczynić, nie porzucając konstrukcji warunku zawieszającego, a regulując tylko trochę inaczej skutki aktu tak pendente condicione, jak i po spełnieniu się warunku (np. wykluczając w myśl intencji stron prawo do żądania zwrotu ceny, a przyjmując retrospekcję w kwestii zasiedzenia). Prawo rzymskie byłoby może poszło tą droga., ale wpływ Juliana inny rozwojowi jego nada 1 kierunek. Chcąc dostosować skutki prawne do właściwości przypadku stworzył on ad hoc konstrukcję wcale sztuczną: rozciął mianowicie akt dokonany pod warunkiem rozwiązującym na dwie części, z których pierwszą stanowi akt uwolniony już od warunku jako "negotium 


\section{Dodatkową trudność sprawia już wyżej wspomniany fakt, że prawo} kanoniczne na mocy kanonu 1529 przyjmuje postanowienia prawa cywilnego danego terytorium dotyczące kontraktów zarówno ogólne jak i szczegółowe, chyba że przeciwstawiałyby się prawu Bożemu, albo prawo kanoniczne w konkretnym wypadku co innego by postanawiało ${ }^{12}$.

purum« drugą czynność mającą na celu »rozwiązanie« tj. usunięcie skutków części pierwszej, a od warunku zawisła. Według konstrukcji tej warunek jest zawieszającym co do umowy o rozwiązanie, której skuteczność od niego jest zależna, ale spełnienie się warunku sprowadza skuteczność tej umowy o rozwiązanie, wobec czego warunek w stosunku do aktu głównego przedstawia się jako rozwiązujący. Konstrukcja powyższa spełnia doskonale zadanie przy interesach obligacyjnych, wyklucza np. przy in diem addictio prawo kupującego do zwrotu ceny kupna pendente condicione, pozwala mu natomiast żądać na powrót towaru, gdyby go w tym czasie nie zwrócił, uważając błędnie warunek za spełniony i umowę dyssolucyjną za skuteczną; po spełnieniu się warunku przeprowadzenie zwrotu nie nasuwa trudności, a nawet temu, że skargę o zwrot trudno uważać za skargę z kontraktu, skoro finita est emptio, nie przypisuje prawo rzymskie większego znaczenia, uważając oznaczenie actionis w tym przypadku za kwestię li tylko formalną. Także stanowisko nabywcy jako posiadacza rzeczy układa się na podstawie owej konstrukcji zgodnie $\mathrm{z}$ wolą stron: emptio pura daje mu tytuł, więc podstawę do zasiedzenia i prawo własności na owocach, które trudno byłoby usprawiedliwić uważając kontrakt kupna pendente condicione za bezskuteczny, a które nie wyklucza zresztą obligacyjnego obowiązku zwrócenia owoców existente condicione. Skoro jednak chodzi o skutki prawa rzeczowego, w szczególności o kwestie własności, sprawa się komplikuje. Jeżeli na podstawie emptio pura nastąpiła tradycja i na kupującego przeszła własność, wówczas sprzedający własność traci; późniejsze spełnienie się warunku zobowiązuje kupującego do zwrotu, ale tylko jego zobowiązuje, nie przenosi na powrót własności na sprzeda w cę, krótko mówiąc działa tylko obligacyjnie, nie wywoluje rzeczowych skutków. Konsekwencje tego nie są dla sprzedawcy korzystne. Kupujący jako właściciel może tymczasem rzecz alienować, może ją obciążyć służebnościami, zastawem (D. 20,6, 3), a sprzedawca nie może w pierwszym przypađku wystąpić przeciw trzeciemu nabywcy, nie może zakwestionować praw wierzyciela zastawnego, bo z umowy dyssolucyjnej ma tylko prawo przeciw kupującemu, prawo względne, które także w razie konkursu kupującego niższość swą w porównaniu z prawem bezwzględnym jasno okazuje (wyżej s. 233)”. [...] ,Juryści rzymscy rzeczowy skutek spełnienia warunku rozwiązującego w inny usprawiedliwiają sposób, wyzyskują tu mianowicie przede wszystkim kontrast prawa cy wilnego i pretorskiego (wyżej s. 69), a przyznaną sprzedawcy actionem in rem uważają za objaw dawnej jego własności, występującej w całej pełni "existente condicione«: kupujący mimo "pura emptiou dostaje tylko własność prawa pretorskiego, która w właściwej chwili znika z powierzchni. Ta myśl jednak w niejednym przypadku nie usuwa trudności: już przy tradycji rei manicipi nie dopisuje po zasiedzeniu rzeczy, więc nabyciu własności kwirytarnej przez kupującego, tak samo jak w przypadku, gdy sprzedawca nie poprzestał na tradycji, lecz dokonał także mancypacji; tym bardziej nie da siẹ na kontraście iuris civilis i honorarii oprzeć nec manicipi, których tradycja przenosi własność cywilną. Źródła nie pozwalają na stanowczą odpowiedź, czy juryści rzymscy rezygnowali w tych przypadkach z skutku rzeczowego, poprzestając na obligacyjnym obowiązku kupującego do zwrotu, czy przeciwnie starali się i tutaj skutek rzeczowy utrzymać i jakich do tego używali sposobów. Jeżeli sprzedawca rzecz mancypował, czynił to zapewne dobrowolnie, gdyż trudno przypuścić, by kupujący mógł do tego zmusić pendente condicione; wobec tego można było niewątpliwie poprzestać na przyznaniu mu obligacyjnego prawa do zwrotu”. - Wróblewski St., dz. cyt., $391 \mathrm{nn}$.

12 ,- Quae ius civile in territorio statuit de contractibus tam in genere, quam in specie, sive nominatis sive innominatis, et de solutionibus, eadem iure canonico in materia ecclesiastica iisdem cum effectibus serventur, nisi iuri divino contraria sint aut aliud iure canonico caveatur". - Kan. 1529. 
Przy zawieraniu zatem czy egzekwowaniu jakichkolwiek innych kontraktów oraz rozwiązywaniu powstałych przy nich wątpliwości należy posługiwać się pojęciami i normami ustalonymi przez prawo cywilne dla danego terenu. W konsekwencji cywilne pojęcie kontraktu warunkowego ma zastosowanie we wszystkich tego rodzaju transakcjach dotyczących dóbr materialnych.

Z kolei warto zauważyć, że podstawowy podział aktów warunkowych - pomijając wyżej zasygnalizowaną różnicę - zarówno w aktualnym prawie kanonicznym oraz jego historii, jak w prawie cywilnym i rzymskim jest zasadniczo zgodny. Te zestawienia i spostrzeżenia pozwolą nam jaśniej wyodrębnić interesujący nas bezpośrednio problem.

\section{Rodzaje aktów warunkowych}

We wszystkich trzech wyżej wspomnianych prawodawstwach nie sa warunkami w ścisłym tego słowa znaczeniu.

$1^{\circ}$ warunki tzw. prawne (conditiones iuris), jak przesłanki, których prawo domaga się, by należycie dokonać aktu prawnego. Będą to np. $\mathrm{w}$ prawie kanonicznym wymogi stawiane do alienacji ${ }^{13}$ rzeczy kościelnych czy drogocennych, a w prawie państwowym np. zawarta w art. 160 $\S 2$ Kodeksu Cywilnego konieczność uzyskania uprzednio od właściwego organu władzy zezwolenia, by mogło być dokonane w drodze umowy nabycie nieruchomości przez osobę prawną.

$2^{\circ}$ Podobnie warunkami w ścisłym tego słowa znaczeniu nie nazywa się uzależnienia danego aktu prawnego od zdarzenia przeszłego, względnie równoczesnego. W chwili bowiem dokonywania aktu sama okoliczność, czy samo zdarzenie już miało miejsce, lub aktualnie się dokonuje. Z tego też powodu akt prawny zaraz osiąga swoją pełną wartość. Konkretna zaś zależność może mieć uzasadnienie psychologiczne dla osoby dokonującej danego aktu, ponieważ nie zna ona jeszcze zdarzenia, na którym jej zależy.

$3^{\circ}$ Również nie podciąga się pod warunki w ścisłym tego słowa znaczeniu uzależnienia czynności prawnych od zdarzeń, które muszą nastąpić. Jeśli bowiem chciałoby się taki akt zaliczyć do racjonalnych, wówczas byłby on zbliżony do pojęcia ,terminu”, od którego ewentualnie mogłaby działać skuteczność czy ważność aktu prawnego.

Natomiast warunek $\mathrm{w}$ ścisłym tego słowa znaczeniu tzn. uzależnienie powstania lub ustania skutku czy ważności aktu prawnego od zdar z enia przyszłego i niepewnego dzieli się w sposób następujący:

13 Por. Kan. 1530, 1531, 1532 etc. 
$1^{\circ}$ na warunki zawieszające i rozwiązujące w zależności od tego, czy w wypadku zaistnienia lub nie zdarzenia uprzednio niepewnego akt prawny nabiera pełnej swojej skuteczności (ważności), lub też z chwilą ziszczenia się warunku ustaje.

$2^{\circ}$ na dodatnie i ujemne w zależności od tego, czy dane zdarzenie, czy okoliczność niepewna ma nastąpić, czy nie ma nastąpić, czy ktoś ma coś uczynić, względnie nie uczynić.

$3^{\circ}$ zależne od woli konkretnej os oby (potestativa); czy té od przyczyn od człowieka niezależnych, lub też mies z a n e. W pierwszym wypadku ziszczenie się warunku zależy od czynności konkretnej osoby, lub kilku osób. W drugim wypadku ziszczenie się określonego zdarzenia jest od człowieka niezależne np. zależy od działania sił przyrody. Trzeci wypadek mieszany, kiedy częściowo jest zależne od człowieka, częściowo nie.

Biorąc pod uwagę rozważany problem oczywistą jest rzeczą, że może wchodzić $w$ rachubę, jeśli chodzi o pierwszy z wymienionych podziałów jedynie warunek zawieszający, nigdy zaś rozwiązujący, ponieważ małżeństwo w Kościele katolickim raz ważnie zawarte i dopełnione nie może być rozwiązane $\mathrm{w}$ zależności od woli stron. Warunek natomiast zawieszający może być, czy to dodatni, czy ujemny, zależny od woli stron (conditio potestativa), lub od innych czynników, czy też mieszany.

Ażeby dojść do źródeł odmiennej koncepcji, warto kolejno przejść posżczególne etapy rozwoju myśli prawniczej dotyczącej tego zagadnienia.

\section{Stary Testament - mentalność Izraela}

Pojęcie aktu warunkowego nie jest czymś nowym dla Izraela, już bowiem w Księdze Kapłańskiej rozdz. 26 w. 3 jest powiedziane: „Jeżeli będziecie postępować według moich ustaw i będziecie strzegli przykazań moich wprowadzając je w życie, dam wam..." W dalszym ciągu wymienione jest w w. 4 do 13 to, co Bóg udzieli ludowi, jeżeli będzie mu wierny: daje urodzaj, plony, pokój itd. Natomiast w. 14 zawiera drugi wariant: „Jeżeli zaś nie będziecie mnie słuchać i nie będziecie wykonywać tych wszystkich nakazów, jeśli będziecie gardzić moimi ustawami, jeżeli będziecie się brzydzić moimi wyrokami tak, że nie będziecie wykonywać moich nakazów i złamiecie moje Przymierze, to i ja obejdę się z wami odpowiednio..." W następnych wierszach omawia konsekwencje takiego postępowania: nieurodzaj, wojny itp., a następnie w razie dalszego wewhętrznego uporu stopniowo coraz cięższe kary.

Jest to typowe uzależnienie określonego działania jednej strony od postępowania drugiej z tym jednak, że postępowanie Boga jest z góry zde- 
terminowane, uzależnione od postępowania ludu izraelskiego. Mówiąc językiem współczesnym warunek ten zależy od działania jednej ze stron (conditio potestativa). Jest tu więc mowa o istnieniu, względnie nieistnieniu konkretnych zdarzeń w zależności od postępowania drugiej strony ${ }^{14}$.

Podobna treść i podobne uwarunkowanie zależnie od posłuszeństwa, względnie nieposłuszeństwa Izraela mamy w Księdze Powtórzonego Prawa rozdz. 28, 1-68. Analogiczne sformułowania możemy też znaleźć w innych miejscach Starego Testamentu np. Księga Wyjścia 23, 22-33.

Inny przykład bardzo charakterystyczny działań prawnych zawartych w Starym Testamencie stanowi umowa między Jakubem a Labanem o zapłatę za pracę. Otóż Jakub proponuje, aby jako zapłatę za diugoletnią pracę należały do niego wszystkie jagnięta cętkowane, pstre i czarne oraz podobne koźlęta spośród stada kóz. Jeżeliby natomiast przy sprawdzaniu Laban po pewnym czasie znalazł wśród jego stada jakąś owcę, czy koźlę, które nie byłoby cętkowane, może je uważać za skradzione ${ }^{15}$. Gdyby zatem Jakub przy oddzielaniu trzody należnej mu za zapłatę nie dostosował się do umowy, to wówczas czynność ta byłaby $n$ i e w a ż $n$ a i naruszyłby prawo własności Labana.

Inny przykład warunkowej decyzji mamy w Księdze Liczb, która referuje polecenie Mojżesza w stosunku do Gadytów i Rubenitów. Jeżeli zdolni do walki ruszą z Izraelitami przez Jordan, wówczas otrzymają w posiadanie krainę Gilead. Gdyby nie ruszyli z nimi do walki, wówczas dostaliby krainę między Izraelitami w ziemi Kanaan ${ }^{16}$. A zatem przy-

$14 \mathrm{Kpl} 26,3-39$.

15 „Gdy Rachela urodziła Józefa, Jakub rzekł do Labana: "Zwolnij mnie, abym mógł wrócić do kraju, w którym mieszkałem. Pozwól mi zabrać moje żony i dzieci, za które ci służyłem, i odejdę. Wiesz dobrze, jak ci służyłem«. Laban mu odpowiedział: "Obyś był mi życzliwy! Odgadłem bowiem, że Jahwe błogosławi mi dzięki tobie . Po czym dodał: „Ustal mi twoją zapłatę, a ja ci ją dam«. Jakub rzekł do niego: "Ty sam wiesz, jak ci służyłem i jaki jest twój dobytek dzięki mnie. Miałeś bowiem niewiele, zanim przyszedłem; odtąd zaś tu jestem, pomnożył się on bardzo i Jahwe ci błogosławi. Jednak teraz muszę się zatroszczyć i o moją rodzinę". A na to Laban: "Cóż więc mam ci dać? " Jakub odpowiedział: "Nic mi nie dasz! Uczyń tylko to, co ci powiem, a będę nadal pasł twe stada i będę się nimi opiekował. A więc: obejdę dzisiaj wszystkie twe stada i wybiorę z nich dla siebie wszystkie jagnięta cętkowane, pstre i czarne spośród owiec oraz koźlęta pstre i cętkowane spośród kóz. Niech one będą moją zapłatą. Po pewnym czasie będziesz mógł przekonać się o mojej uczciwości. Gdy bowiem przyjdziesz, aby obejrzeć to, co będzie mi się należało jako zapłata, kozy, które nie będą cętkowane i pstre oraz owce, które nie będą czarne, możesz uważać za skradzione przeze mnie«. - Rdz 30, 25-43. Pismo Swięte Starego i Nowego Testamentu, Poznań-Warszawa $1971^{2}, 47$.

16 ,Wydał więc Mojżesz rozporządzenie kapłanowi Eleazarowi, Jozuemu, synowi Nuna, i głowom rodów pokoleń izraelskich. Rzekł do nich Mojżesz: 》Gdy wszyscy Gadyci i Rubenici zdolni do walki ruszą z wami w obecności Jahwe przez Jordan na wojnę, i ziemia zostanie przez was pobita, dajcie im w posiadanie krainę Gilead. Jeśliby jednak wojownicy nie ruszyli z wami, otrzymają posiadłość pomiędzy wami w ziemi Kanaan«". - Lb 32, 28-30. Tamże, 167. 
dział tej czy innej ziemi dla Gadytów i Rubenitów został uzależniony od ich pójścia, względnie niepójścia z Izraelem do walki.

Podobnych przykładów można by przytoczyć więcej. Znamienną jest jednak rzeczą, że samo dokonywanie działań prawnych o charakterze warunkowym nie było obce narodowi izraelskiemu. Ponadto warto zwrócić uwagę, że w przytoczonych przykładach nie widać koncepcji „,skuteczności aktu" lecz jego wa żność. Is t nie ni e tego czy też innego wariantu zależy od wypeinienia warunku.

W późniejszym prawie żydowskim znane było również i małżeństwo zawarte warunkowo, jednakże - jak to wykazuje Rudolf Weigand akt warunkowy tego rodzaju szczególnie w Talmudzie nabiera cech formalizmu. Zasadniczą myśl tej doktryny przedstawia wspomniany autor $\mathrm{w}$ podsumowaniu ${ }^{17}$. Od formy użytych słów zależą prawne konsekwencje aktu warunkowego. Wewnętrzna intencja nie miała wówczas wpływu na ważność czy nieważność danego aktu. Słowa bowiem a nie intencja określają praktycznie rodzaj warunku, o jaki w danym wypadku chodzi. W prawie żydowskim istnieje duża różnica między dzisiejszą doktryną dotyczącą małżeństw warunkowych a tą, która miała miejsce w okresie powstawania tradycji talmudycznej i jej spisywania. Szczególnie zaś, kiedy odstęp między pierwszymi, czyli „,prawnymi”, zaślubinami a uroczystym rozpoczęciem pożycia małżeńskiego był większy, wypadki zawierania małżeństw warunkowych zdarzały się częściej. Gdy jednak okres ten uległ skróceniu, występował rzadziej ${ }^{18}$. Przy pierwszym więc akcie zaślubin, czyli prawnym zawieraniu małżeństwa dodawano nieraz waru-

17 ,Abschliessend kann man sagen: Das eigentliche Kennzeichen der jüdischen Bedingungslehre ist ihr Formalismus. Von der Form der gewählten Worte hängt es $a b$, welche Wirkung die Bedingung hat. Eine andere innere Willenshaltung hat keinen Einfluss auf Gültigkeit oder Ungültigkeit der Bedingung. Auch in diesem Fall entscheiden die gebrauchten Worte und die aufgestellten Regeln über die Wirkungen der verschiedenen Arten der Bedingung.

Bezüglich das tatsächlichen Vorkommens der Bedingung im jüdischen Eherecht ist ein grosser Unterschied zwischen früher und heute. In talmudischer Zeit, als die Antrauungen lange vor der Hochzeit stattfanden, waren die bedingten Antrauungen naturgemäss häufig. Seitdem aber Antrauung und Hochzeit zu einer einzigen feierlichen Handlung vereinigt wurden, sind die Bedingungen hierbei seltener geworden, ja kaum mehr vorgekommen, so dass es die heute praktisch nicht mehr gibt.

Dagegen sind die Bedingung bei den Verlöbnissen (Schiddukin) gang und gebe, insbesondere bei den Juden osteuropäischer Herkunft. Ja, die Verlöbnisse werden häufig einfach Tenaim genannt, also mit dem gemeinsamen Wort für Vereinbarung und Bedingung bezeichnet. "In der Bedingungsurkunde werden Bedingungen festgelegt, die der Vater des Bräutigams und der Vater der Braut bzw. deren Vertreter aufstellen. Diese werden die Tenaim Rischonim genannt. Es gibt ausserdem eine Urkunde der Bedingung vor der Trauung, und das sind die Bedingungen der Ketuba, oder auch Tenaim Acharonim genannt«. Dabei muss man jedoch im Auge behalten, dass nicht alles, was Tenaim genannt wird, auch eine Bedingung im juristischen Sinne ist. Häufig sind mit Tenaim einfach die Vereinbarungen des Verlöbnisses oder der Ketuba gemeint". - Weigand R., Die bedingte Eheschliessung im kanonischen Recht, München 1963, 86.

18 Weigand R., tamże, 87. 
nek. Zgodnie też z ówczesną nauką od spełnienia czy niespełnienia się warunku zależała ważność c zy nieważność danego związku małżeńskiego, szczególnie, jeśli były to warunki odnoszące się do stanu aktualnego, czyli conditio de praesenti. A zatem w wypadku niewypelnienia się warunku małżeństwo było uważane $\mathrm{za} n$ i e ważne i żona mogła być oddalona bez listu rozwodowego ${ }^{19}$.

\section{Prawo rzymskie}

W prawie rzymskim używanie warunku było bardzo oszczędne. Częściej mogło się to zdarzyć w wypadku zwykłych kontraktów, nie stosowano go natomiast do małżeństwa. Tłumaczą to różni autorzy w rozmaity sposób. Zasadniczo przyjęta jest teoria, że małżeństwo rzymskie było uważane za zaszłość faktyczną, od którego to momentu trwał consensus continuus ${ }^{20}$. Inni autorzy wspominają jeszcze, że do małżenstwa dlatego nie można było dołączyć warunku, ponieważ stanowiło ono akt prawny czynność prawną uroczystą, składającą się z coemtio i confarreatio ${ }^{21}$. Byli i tacy, którzy uzasadniali to inaczej: małżeństwo powstaje ze stypulacji,

19 „Bei der Eheschliessung selbst sind Bedingungen kaum vorgekommen, da sie mehr der feierliche Anfang des Ehelebens war, während das rechtliche Moment mit der Enstehung der Treupflicht im wesentlichen auf die Antrauung entfiel. Doch wirkte sich eine Bedingung bei der Antrauung der überwiegenden Lehre zufolge auch auf die Gültigkeit bzw. Ungültigkeit der nachfolgenden the aus, vor allem wenn es sich um einen in der Gegenwart vorhandenen oder nicht vorhandenen Umstand oder eine Eigenschaft handelte. Bei Nichterfüllung der Bedingung konnte die Frau ohne Scheidebrief entlassen werden". - por. Weigand R., tamże, $412-413$.

20 Rasi P., Consensus facit nuptias, Milano 1946, 103.

21 Rasi P., tamże, 103: „Condizione. Si suole scrivere che nel matrimonio romano non si può parlare di condizione perchè si tratta di un rapporto di mero fatto (Cosi BONFANTE, DI MARZO, ARANGIO-RUIZ), o di un neg o z i o gi u ridico solenne, per quanto riguarda i matrimoni per coemptio e confarreatio (por. tamże przyp. 2): ,(MANENTI, Della inapponibilità delle condizioni ai negozi giuridici ed in ispecie alle condizioni apposte al matrimonio, Sienia 1889, p. 35, naturalmente solo nei riguardi dei matrimoni cum manu); pur per altre ragioni concordo con l'opinione comune”; Por. Weigand R., dz. c., s. 43-44: „Für das nachklassische und justinianische $\mathrm{E} h$ e $\mathrm{r}$ e $\mathrm{ch}$ t zeigt sich in manchen Fragen eine Angleichung der verschiedenen Auffassungen der modernen Forscher über die römische Ehe, in anderen eine weitergehende Differenzierung der Standpunkte. Der Grund hierfür liegt besonders in der unterschiedlichen Beurteilung des christlichen Einflusses auf das römische Eherecht. Obwohl in letzter Zeit darüber manche $\mathrm{Ab}-$ handlugen erschienen sind, ist diese Frage noch keinswegs geklärt und es wird noch mancher Forschungsarbeit bedürfen, bis eine allseitig befriedigende Lösung gefunden ist. In der Beurteilung der tatsächlichen Situation besteht im grossen und ganzen Übereinstimmung, aber nicht in der Frage der den einzelnen Verordnungen und Erscheinungen zugrunde liegenden Ehelehre (...) tamże, 413: „Im rö$\mathrm{mischen} \mathrm{Recht} \mathrm{gab} \mathrm{es} \mathrm{keine} \mathrm{bedingte} \mathrm{Eheschliessung.} \mathrm{Sie} \mathrm{war} \mathrm{von} \mathrm{vornherein}$ unmöglich und unnötig, weil die Eheschliessung keine vertragsähnliche Rechtshandlung war, sondern ein Brauchtum und Sitte entwickelter und gestalteter Vorgang, mit dem nur mehr indirekt manche Rechtswirkungen verbunden waren. Als verwirklichte Lebensgemeinschaft konnte die Ehe naturgemäss nicht bedingt eingegangen werden. Das wäre eine theoretische und praktische Unmöglichkeit gewesen". 
a ten akt prawny nie przyjmuje warunków zależnych od niepewnego losu 22. Większość jednak autorów współczesnych wypowiada się za pierwszą teorią, że małżeństwo uważano za zaszłość faktyczną, do której prawo dołączało skutki prawne.

Można by mieć pewną wątpliwość w okresie po Auguście, czy to ze względu na upadek dokonywania aktów prawnych w formie stypulacji, czy to przez zaistnienie nowych zasad socjalnych. Niektórzy utrzymują, że wówczas możliwe było dołożenie warunku rozwiązującego do małżeństwa. Biorąc jednak pod uwagę system rzymski, trzeba powiedzieć, że nie można mówić o małżeństwie warunkowym szczególnie $\mathrm{z}$ warunkiem rozwiązującym, lecz najwyżej o małżeństwie czystym (actus purus), do którego dołączona została umowa przeciwna i warunkowa, albo umowa rozwiązująca, uzależniona od spełnienia się warunku ${ }^{23}$. Ważność takiej umowy warunkowej dołączonej do małżeństwa wydają się przyjmować i słynni prawnicy rzymscy np. Ulpian mówiąc o zawarciu małżeństwa z umową dołączoną: ,ut si civem Romanum [...] uxorem duxerit, testatione interposita, quod liberorum quaerendorum causa uxorem duxerit". (Dom. Ulpiano, Fragmenta, III, de latinis 3). Inny tekst potwierdzający ten sui generis warunek można znaleźć np. u Marcobia ${ }^{24}$, gdzie stwierdza on, że warunek liberorum quaerendorum causa jest nie tylko dopuszczalny, ale także i religijnie moralny. Jest to stwierdzenie bardzo znaczące.

Jednakże Rasi w cytowanej książce słusznie chyba zamieszcza uwagę, że w tym wypadku nie chodzi o jakąś umowę dołączoną do kontraktu małżeńskiego, lecz konkretnie o wyrażenie zasadniczego celu, albo też przyczyny skłaniającej do zawarcia małżeństwa ${ }^{25}$. Uzasadnieniem jego

22 Rasi P., dz. cyt., 103: ,[...] ritengo anch'io che non si potessero apporre condizioni al matrimonio, solo perchè esso nasceva da una stipulatio, negozio che non sopportava condizioni di sorta".

23 Tamże.

24 Marcobio, Sturnalia 1, 16, 18: „Uxorem liberorum causa ducere religiosum est." Por. Rasi P., dz. cyt., 104: ,Interessante notare che per lo più il patto o la clausola veniva inserito nelle tabulae nuptiales: Quid cuncubitus conjugalis, qui secundum matrimonialium praescripta tabularum procreandorum sit causa liberorum (S. Agostino, De civit. Dei, XIV, 18); adhibitis qui obsignarent, velut suscipiendorum liberorum causa (Tacito, Annales, XI, 27.). E Tacito che ci racconta che Messalina desiderosa di sposarsi ,regolamente” con Silo, pur all'insaputa di Claudio, trasse gli auspici, sacrificiô agli dei, e richiese l'intervento di coloro che dovevano far risultare (adhibitis qui designarent) che ella si sposava per aver figli (velut suscipiendorum liberorum causa). Forse si può ritenere che tale clausola doveva risultare da atto scritto ricevuto da determinate persone".

25 Rasi, dz. cyt., 104: „Penso perô che non si tratti di ,condizione” o di ,patto aggiunto" al contratto di matrimonio, e ciô sopratutto per la natura del negozio giuridico che derivava da una stipulatio: ritengo invece che trattasse del fine principale o o meglio dire della causa del matrimonio. Mi spiego più chiaramente. Per la Lex Iulia Miscella o Papia Poppaea il martio morendo poteva lasciare alla moglie una quota di eredità sotto condizione di vedovanza; ora la vodova poteva risposarsi, senza perdre i suoi diritti ereditari, solo se giurava che contraeva matrimonio: liberorum causa (4) (ROTONDI, Leges Publicae, cit., pag. 458.). Qui non si pone una 
argumentacji, jak podaje, jest Lex Julia Miscella o Papia Poppaea, na mocy którego mąż umierając mógł zostawić żonie pewien spadek pod warunkiem, by nie wyszła powtórnie za mąż. Gdy jednak żona później z racji liberorum quaerendorum causa nie dotrzymała zobowiązania, nie traciła przez to uprawnień dziedzicznych.

Począwszy od Konstantyna doktryna ojców Kościoła dopomogła do tego, że małżeństwo zaczęto uważać jako pewnego rodzaju umowę kontrakt, który powstaje przez wzajemną zgodę ${ }^{\mathbf{2 6}}$, i dlatego podlega tym samym co i inne prawom odnośnie do możliwości stosowania warunku. Jednakże trzeba pamiętać o pewnej, wspomnianej już wyżej, niechęci do stosowania aktów warunkowych u Rzymian i dlatego zdarzały się one raczej rzadko.

\section{MAEZEŃNTWO WARUNKOWE W HISTORII PRAWA KANONICZNEGO}

\section{Warunkowe zawarcie zaręczyn}

W Kościele od początku panowała zasada, że narzeczeni poprzez wolną i na serio podjętą decyzję zawiązują węzeł małżeński. W tym wypadku niejako istnieje pewna zbieżność między zasadą prawa rzymskiego: consensus facit nuptias i nauką prawa kanonicznego z tą tylko różnicą, że w prawie rzymskim, jeśli chodzi przynajmniej o niektóre wypadki wymagano oprócz zgody samych zainteresowanych również zgody tego, kto względem nich posiadał patria potestas. W Kościele natomiast sama zgoda zainteresowanych od początku miała znaczenie decydujące pomimo, że

condizione ma si dichiara il fine per cui si stringe un negozio giuridico. Ed infatti si prende in considerazione solo il momento iniziale, non quelli successivi, nulla influendo la circostanza che i figli vengano o meno (5) (2, C., 6, 40; 3, C., 6, 40, Nov., 22, 43 e 44 )".

${ }_{26}$ "Ia Chiesa fin dalle sue origini ritenne che il consensus comunque manifestato dei sposi, purchè serio e libero, facesse sorgere il vinculum matrimoniale, e ciô anche se non interveniva la effettiva esecuzione, consensus facit nuptias.

L'unico vero contrasto, forse, riguardava le persone che dovevano manifestare il consensus; mentre infatti per il diritto romano questo doveva, almeno in alcuni casi, essere espresso dai nubendi e da coloro che avevano la patria potestas su di essi, per la Chiesa solo la voluntas dei primi aveva valore giuridico in quanto era su di essi che scendeva la grazia sacramentale". Piero Rasi, La conclusione del matrimonio nella dottrina prima del Concilio di Trento, Napoli 1958, 25. Por. Weigand R., dz. cyt., 413: „In dem Nasse als im justinianischen Recht die Ehe allmählich zu einem Rechtsverhältnis erstarkte, das nicht mehr auf die Fortdauer des EhewilIens der Gatten angewiesen war, könnte man zwar mit der Möglichkeit rechnen, dass der Versuch zu einer bodingten Eheschliessung gemacht worden wäre. Tatsächlich finden sich aber auch im justinianischen Recht keinerlei Spuren hiervon. Wenn das Problem im justinianischen Recht zu entscheiden gewesen wäre, so wäre ziemlich sicher die zweitte oben angedeutete Regelung gewählt worden: Wegen des Erfordernisses der Rechtssicherheit wäre eine bedingte Eheschliessung für unmöglich gehalten worden und die Befügung einer Bedingung bei der Eheschliessung hätte die Unwirksamkeit der Eheschliessung zur Folge gehabt, ähnlich wie das in der Rechtsregel Dig. 50. 17. 77 für andere bedingungsfeindliche Rechtsvorgänge verfügt ist". 
w ciągu wieków rozmaite były oddziaływania na jego doktrynę. $\mathrm{O}$ ile z jednej strony wpływ nauki Ojców na prawo rzymskie bardziej jeszcze utwierdził pojęcie zgody małżeńskiej w formie kontraktu, o tyle niechęć i ostrożność Rzymian do zawierania aktów warunkowych, a w szczególności małżeństwa tak silnie oddziałała na prawo kanoniczne, że przez długi czas autorzy powołują się na zasady rzymskie nie dopuszczające przynajmniej teoretycznie do zawierania małżeńsiw warunkowych.

Przed Gracjanem nie znajdujemy śladów må̇żeństw warunkowych. Są jednak dwa teksty, ale nie dotyczą one małżenstwa warunkowego w ścisłym tego słowa znaczeniu. Jeden z nich pochodzi z synodu partykularnego, autorem zaś drugiego jest św. Augustyn. W obu wypadkach chodzi o postanowienie zawarcia związku z osobą nieochrzczoną, decydującą się na przyjęcie chrześcijaństwa. A zatem nie chodzi jeszcze o małżeństwo, lecz - jak byśmy w dzisiejszym języku powiedzieli — o zaręczyny, które są zawarte pod warunkiem nawrócenia. Również późniejsi komentatorowie nie widzą w tym przypadku małżeństwa warunkowego, bo gdyby istotnie zostało zawarte, byłoby nieważne z tytułu przeszkody, jaką jest związek z osobą nieochrzczoną ${ }^{27}$.

Dopiero Gracjan po raz pierwszy stawia pytanie wprost, czy można zawrzeć małżeństwo pod warunkiem nawrócenia się na wiarę chrześcijańską drugiej strony? Odpowiedzi jednak na to nie daje. Pytanie powyższe postawił Gracjan w swoim dictum na początku C. 32 q. 8 w nr 8. Jeśli chodzi o komentatorów Gracjana warto zwrócić uwagę na paleę do C. 27 q. 2 c. 7, w której autor powołując się na Sobór Afrykański nie dopuszcza możliwości zawarcia małżeństwa pod warunkiem i drugą do C. 27 q. 2 c. 8. W tej ostatniej komentator twierdzi, że pomimo warunku związek trwa, ponieważ warunek ,fragatur', czyli: nie ma zdolności skutecznego działania ${ }^{28}$. Jednałże w wielu wcześniejszych rękopisach między

97 Wernz Fr., Ius Decretalium t. IV pars II-a, Prati 1912, 83. Por. Weigend R., dz. cyt., 414: ,B is z u Grat i a n finden sich keine Spuren einer bedingten Eheschliessung im eigentlichen Sinne. Wohl aber gibt es einige Synodalbestimmungen (und eine Stelle bei Augustinus), die Ehen zwischen Gläubigen und Un-bzw. Irrgläubigen nur dann für erlaubt erklären, wenn sich der Un-bzw. Irrgläubige zu bekehren verspricht. In diesem Falle war die erlaubte Eingehung der Ehe von dem Versprechen der Bekehrung abhängig. Nicht die Ehe war bedingt, sondern der Entschluss zur Ehe war - oder sollte es den Gesetzen entsprechend wenigstens sein — von dem Versprechen der Bekehrung abhängig un durch es bedingt".

28 Weigand R., dz. cyt., 103: „(C. 27 q. 2 c. 7) Quod condicio interposita non ualeat, ex concilio affricano probatur. (C. 27 q. 2 c. 8) Quicumque sub condicionis nomine aliquam desponsauerit et eam postea relinquere uoluerit, dicimus, quod condicio fragrantur et äesponsatio irrefragabiliter teneatur".

NB. Ponieważ w wyżej cytowanym dziele są zebrane teksty dekretystów i nielktórych dekretalistów wraz ze starannie przygotowanym aparatem krytycznym, a nie są w peìni wykorzystane pod aspektem omawianego przeze mnie zagadnienia, dlatego będę się posiugiwał tekstami przez R. Weiganda opublikowanymi, tym bardziej, że wiele $z$ nich jest w Polsce niedostępnych, lub przynajmniej nie w krytycznym wydaniu. 
innymi w gdańskim manuskrypcie pod sygnaturą Mar. F. 77 (XIII w.) nie ma ani jednej ani drugiej $\mathrm{z}$ tych palei. Zwrócił na to uwagę $\mathrm{w}$ swoich badaniach prof. Vetulani ${ }^{29}$. Na podstawie porównania z innymi manuskryptami Rudolf Weigand dochodzi do wniosku, że zostały one dodane pod koniec XII w. ${ }^{30}$. Ponadto sformułowanie szczególnie drugiej palei jest nieprecyzyjne, nie pozwala na wyciągnięcie konkretnych wniosków, dlatego też rozmaicie ją $\mathrm{w}$ historii interpretowano ${ }^{31}$.

Bardziej konkretną odpowiedź na pytanie postawione przez Gracjana daje Rufin w komentarzu do C. 28 q. 1 c. $16^{32}$, w którym wyraźnie rozróżnia dwa wypadki. O ile nie wolno chrześcijaninowi wziąć za żonę niechrześcijanki, lub wyznającej herezję, o tyle dopuszcza możliwość przyrzeczenia przyszłego małżeństwa pod warunkiem nawrócenia się strony niekatolickiej. W dalszym tekście powołuje się na Synod Afry.kański, o którym wspominała już poprzednio cytowana palea i stwierdza, że warunek nie zostaje wzięty pod uwagę, a przyrzeczenie zachowuje swą wartość. Nie pozostawia tego jednak bez równoczesnego wyjaśnienia. Wypadek bowiem rozpatrywany na synodzie dotyczy warunku niegodziwego, gdyby jednak warunek był godziwy, można go przyjąć.

\section{Godziwość warunku i modus qualificatus}

Wyjaśnienie Rufina jest dla przyszłej wiedzy kanonicznej ważne, ponieważ u następnych dekretystów, a później i dekretalistów stale będziemy się spotykać z tym samym stwierdzeniem, że przyrzeczenie odnośnie przyszłego małżeństwa, czyli według dzisiejszej nomenklatury - narzeczeństwa, może być zawarte pod warunkiem, o ile jest on godziwy. O ile warunki niegodziwe uważane są za niedodane do umowy, o tyle godziwe należy uznać za ważne i respektować. Trudno stwierdzić z kontekstu, czy w danym wypadku przyjęty przez Rufina warunek odnośnie zaręczyn jest pojmowany według pojęć rzymskich jako wywołujący skutki prawne $\mathrm{w}$ wypadku ziszczenia się, czy też $\mathrm{w}$ wypadku nieziszczenia

29 Studia Gratiana I 259 i 263.

30 Weigand R., dz. cyt., 105.

31 Por. Wernz, dz. cyt., 83.

32 ,(C. 28 q. 1 c. 16) Duo affiguntur hic contraria: unum supra capitulo proximo, ubi cavetur Christiano, ne hereticam vel aliquam a fide sua alienam accipiat in uxorem; alterum supra dist. XXXII Quoniam (c. 15), ubi uxor de alterius secta duci prohibetur. Sed in proximo capitulo supra et in distinctionibus prohibetur accipere, id est in domum ducere vel cognoscere; hic permittitur accipere, id est futurarum nuptiarum promissionem facere, hac tamen conditione, si se profitentur Christianos essefuturos et catholicos. Et hic assurgit contrarium ex concilio africano: ubi dicitur, quod si quis sub conditione aliquam desponsavit, conditio frangatur et desponsatio irrefragabiliter teneatur. Sed ibi de inhonesta conditione agitur, hic vero de honesta". Rufinus, Summa Decretorum, Wyd. H. Singer, Paderborn 1902, 458. NB. Podkreślenie moje. 
sam akt zaręczyn jest nieważny i niebyły. Jednakże w rozwoju wiedzy kanonicznej jeszcze za wcześnie, abyśmy mogli podobne konkluzje wyciągać, ponieważ rozwijają się one stopniowo.

Następny krok w kierunku rozwoju doktryny kanonicznej odnośnie małżeństwa warunkowego czyni Stefan z Tournai, który w swoim komentarzu do C. 28 q. 1 c. 16 czyni rozróżnienie między warunkiem i modum - sposobem ${ }^{33}$. Stwierdza tam, że o ile małżeństwo pod warunkiem nie może być zawarte, o tyle modus dołożony do małżeństwa jest do przyjęcia - ,non excluditur”. Widać tutaj wyraźny wpływ prawa rzymskiego, gdzie to pojęcie było już wyraźne i jasno określone. Modus jednak użyty przez Stefana z Tournai należy nazwać modus qualificatus według nomenklatury rzymskiej, tj. taki, który pociągał za sobą chęć stworzenia obowiązku u drugiej strony, czego nie zawiera w sobie modus simplex ${ }^{34}$.

W dalszym tekście, w komentarzu do C. 32 q. 8, Stefan z Tournai nawiązując do tekstu św. Augustyna wyklucza - co jest rzeczą zrozumiałą - możliwość zawarcia małżeństwa pod warunkiem przez związanego węzłem małżeńskim lub profesją uroczystą. Natomiast, jeśli chodzi o wolnego, wydaje się zgadzać na małżeństwo pod warunkiem nawrócenia ${ }^{35}$. Chociaż wydaje się mówić o małżeństwie zawartym pod warunkiem, to biorąc pod uwagę pojęcia ówczesne i nieodróżnianie przez wielu zaręczyn od ślubu, według dzisiejszej nomenklatury, należy sądzić, że chodziło mu o zaręczyny, ponieważ małżeństwo przed nawróceniem byłoby nieważne z racji przeszkody, o czym wspominają wcześniejsi dekretyści.

\section{Pośredni wpływ szkoły paryskiej}

Stosunkowo wielki wpływ, chociaż zasadniczo pośredni, dał Piotr Lombard stojący na czele szkoły paryskiej, jeśli chodzi o dalszy rozwój formowania się myśli kanonicznej w interesującym nas zagadnieniu. Nie

33 ,Sed dicemus non hic esse condicionem set modum. Aliud enim est dicere: „faciam hoc si feceris illud”, quod est condicio; aliud: „faciam hoc ut facias illud", quod est modus. Condicio autem in matrimonio non "admittitur, modus non excluditur. Vel dicemus turpem condicionem (non admitti honestam ut ista est non respui. Vel speciale est in condicione) sucipiende fidei (B f. 227ra)". Tekst bardziej krytycznie opracowany niż wydanie Schulte'go podaje Weigand R., dz. cyt., 136.

34 Por. Wróblewski St., dz. cyt., 399.

35 "Cum octauo queratur. an liceat alicui fidelium infidelem ea conditione ducere ut ad fidem conuertatur. Non hanc, set aliam uidetur Gratianus prosequi questionem. Coniugato enim uel solenni uoto astricto minime competere infidelem sub predicta conditione ducere auctoritate Augustini probat dicens: „Non solum mechandum non est" ... Verumtamen etsi lateat predicte questionis solutio presenti tamen continetur capitulo, uidelicet ubi dicitur: „quod enim cuidam” etc. Dicimus ergo solutum, id est nec uoto nec copula matrimonii ligatum prefata conditione posse ducere infidelem (f. $81 \mathrm{va} / \mathrm{b}$ )". - Stephanus Tornacensis C. 32 cyt. Weigand R., dz. cyt., 142 . 
tylko przyczynił się do utrwalenia instytucji zaręczyn, lecz także zasadniczą jego zasługą na polu doktryny kościelnej w odniesieniu do małżeństwa było zgłębienie i utwierdzenie nauki Kościoła uznającej wzajemną zgodę małżonków za podstawę węzła małżeńskiego. Szkoła bowiem bolońska usiłowała udowodnić, że o małżeństwie decyduje faktyczne, fizyczne współżycie.

W odniesieniu do małżeństw warunkowych zwrócenie uwagi na istotny element zgody małżeńskiej spowodowało również u zwolenników Piotra Lombarda wpierw zwrócenie uwagi, a później wypracowanie warunków przeciwnych istocie małżeństwa. Na pierwszym miejscu spośród nich wypada wymienić Gandulphus'a z Bolonii, który zagadnienie warunku rozważa w $\S 246$ swoich sentencji ${ }^{36}$. W tekście cytowanym warto podkreślić trzy zasadnicze myśli:

Pierwsza korzeniami swymi sięga do koncepcji rzymskiej odnoszącej się do warunku niegodziwego, którego nie bierze się pod uwagę.

Druga zaś zawiera twierdzenie, że jeżeli pomimo zawarcia małżeństwa pod warunkiem niegodziwym nastąpiło współżycie cielesne, to malżeństwo jest ważne. Gandulphus nie wyjaśnia, czy z powodu tej racji, o której mówił poprzednio, że warunek niegodziwy uważa się za niedołączony ,,conditio inhonesta pro non adiecta habeatur”, czy też z racji współżycia, jakie nastąpiło po warunku, co byłoby równoznaczne z wycofaniem się z zastrzeżenia warunkowego. Stanowiłoby to pewne połączenie koncepcji szkoły paryskiej i szkoły bolońskiej. Warto jednak na to zwrócić uwagę, ponieważ autorzy późniejsi bardzo często właśnie na tę koncepcję będą się powoływali nawet w wypadku warunku godziwego, który zostaje anulowany przez późniejsze pożycie fizyczne, stanowiące - ich zdaniem - o wycofaniu się z aktu warunkowego. Tutaj mamy niejako początek tego rozumowania, chociaż niedokończonego przez autora.

Trzecia wreszcie myśl, zdradzająca u Gandulphus'a niepełne zrozumienie aktu warunkowego, a $z$ drugiej strony przejęcie się podstawowymi założeniami szkoły paryskiej, wyraża pogląd, że tylko zgoda aktualnie wyrażona consensus de praesenti tworzy małżeństwo. Jest ono ważne niezależnie od tego, czy warunek się wypełnił, czy nie. Stanowi to pewnego rodzaju niekonsekwencję, ale trudno żądać od ówczesnego auto-

36 „Quod est: conditio, si turpis fuerit, debet frangi et desponsatio irrefragabiliter teneri. Vel potest desponsatio intelligi traductio, ut si sensus: "Quicumque desponsaverit«, id est traduxerit aliquam, vel sibi per praesentem consensum aliquam copulaverit sub conditione, si turpis fuerit ,conditio frangatur". Vel: si illicita et fracta fuerit, ,desponsatio”, id est huiusmodi copula, ,,irrefragabiliter teneatur". Si enim consensus solus de praesenti matrimonium facit, cum huiusmodi consensus adimpletionem conditionis praecedat, sive adimpleatur conditio sive non, matrimonium erit". - Magistri Gandulphi Bononiensis Sententiarum libri quatuor, Wien-Breslau 1924, wyd. J. v. Walter, 532 n. 
ra, ażeby przewidział wszystkie następstwa. Tekst tak sformułowany zdradza jego przekonanie, że małżeństwo zawierane przez ,aktualny” konsens nie dopuszcza warunku. Nie widać tutaj jednak wpływu koncepcji rzymskiej, lecz zbyt intensywne przejęcie się koncepcją szkoły paryskiej, co doprowadziło go do takiego wniosku. Gandulphus mniema, jak chyba słusznie mówi Weigand, że niemożliwą jest rzeczą, ażeby ważność małżeństwa mogła być uzależniona od przyszłego wypełnienia się warunku, czyli staje na stanowisku natychmiastowej ważności małżeństwa ${ }^{37}$.

Z następnych tekstów kanonicznych mówiących o warunku warto zwrócić uwagę na tekst Sumy Kolońskiej (Summa Coloniensis) w związku z dekretałem C. 28 q. 1 c. 16 . Postawiono wpierw pytanie, czy wolno wziąc za żonę niewierzącą, ażeby ta nawróciła się? W odpowiedzi są zaakcentowane dwa elementy: pierwszy $\mathrm{z}$ nich to stwierdzenie, że $\mathrm{m}$ a żeństwo jest aktem uroczystym i dlatego nie może przyjąć warunku przy jego zawieraniu ${ }^{38}$. Jest to jedna z racji podawanych przez dekretystów dla wyjaśnienia, dlaczego prawo rzymskie nie przyjmuje warunków przy zawieraniu małżeństwa. Następnie powołując się na poprzednio przez innych cytowane teksty przypomina autor Sumy, że warunku niegodziwego nie bierze się pod uwagę, jednak w tym wypadku nie o taki warunek chodzi ${ }^{39}$. Ze względu jednak na nieważność małżeństwa $\mathrm{z}$ osobą niewierzącą - zgodnie $\mathrm{z}$ cytowanym tekstem św. Augustyna - mówi, że nie wolno pojąć za żonę i wprowadzić jej do domu, natomiast godziwą jest rzeczą przyrzec przyszłe małżéstwo w wypadku nawrócenia. Mówiąc dzisiejszym językiem, autor przyjmuje warunkowe zaręczyny, o ile warunek jest godziwy. A zatem zaręc yny pod war unki em są aktem wa żnym, czyli umową, którą należy dochować. Stwierdza bowiem na początku cytowanego tekstu, że zachowanie umów godziwych jest zaaprobowane przez prawo i dobre obyczaje.

Warto podkreślić, że choć Summa Coloniensis robi wzmiankę o niedozwoleniu współżycia przed właściwym małżeństwem, jednak szerzej

${ }_{37}$ Weigand R., dz. cyt., 147.

38 ,Huic clausule due obiciuntur, in primis quod desponsatio sollempnis actus est conditionem non recipit. - Summa Coloniensis f. 136 va cyt. Weigand R., dz. cyt., 152 .

${ }_{39}$,Set hic de inhonesta conditione accipitur. Honesta enim pacta seruare et iure et moribus adprobatum est, ita tamen, ut tametsi conditio adiecta deficiat, matrimonium tamen non infirmetur, quia legitimi actus conditionem non recipiunt. Secundo obicitur quod in disparitate coniugia contrahi prohibentur. Vnde Augustinus: Non debet quis ista compensatione peccare ut ideo credat uxorem sui ducendam, quia promiserit, que nuptias eius appetit, futuram se esse christianam. Ergo accipere, id est in domum ducere uel cognoscere prohibitur. Accipere autem, id est futurarum nuptiarum sub hac conditione pactum facere conceditur (f. 136 va)". Summa Coloniensis, tamże, 152. 
w odniesieniu do warunku rozwija to dopiero Jan Faventinus. W związku z dekretałem C. 32 q. 8 sygnalizuje on, że nie wolno współżyć fizycznie przed dopełnieniem się warunku, a pełniej rozwija on tę myśl powołując się na magistra Rolanda w odniesieniu do C. 28 q. 1 c. 16 . Mówiąc tam o zəwieraniu małżeństwa zwraca uwagę na rozróżnienie między czasem i faktem. Jeżeli bowiem ktoś powie: biorę cię jako swoją, o ile mi dasz tyle a tyle „expirat conditio", czyli nie uwzględnia warunku przy zawieraniu aktualnego małżeństwa, warunek nie wpływa na jego ważność. Gdyby natomiast użył słowa ,te accipiam" w czasie przyszłym, wtedy „tenet conditio" - akt warunkowy jest ważny chyba, żeby przed upływem dnia spełnienia się warunku nastąpiło współżycie fizyczne ${ }^{40}$. Tutaj można dostrzec niewątpliwy wpływ szkoły bolońskiej, której pojęcia rzutują na akt warunkowy, jak to późniejsi autorzy szerzej wyjaśniają. Sam fakt współżycia fizycznego jest niejako równoznaczny z rezygnacją z warunku i zawarciem już aktualnego małżeństwa pomimo warunkowych zaręczyn.

Jeżeli chodzi o problem rozważany, warto zwrócić uwagę na tekst Sumy Monachijskiej (Summa Monacensis). Autor rozróżnia w niej warunki nie wpływające na ważność małżeństwa i takie, bez których spełnienia nie może ono istnieć. Mimo przeciwnych pozorów autorowi nie chodzi tutaj o uzależnienie zaistnienia małżeństwa od samego warunku. Z głębszej analizy tekstu widać, że jest to uzależnienie wynikające $\mathrm{z}$ innych racji. Samo postawienie tego rodzaju problemu jest pewnym krokiem naprzód. Jako przykład warunku, w zależności od którego małżeństwo nie może być zawarte podaje przykład, że: ,zawieram z tobą małżeństwo, jeżeli w posagu wniesiesz tyle a tyle". Natomiast warunek, z którym może być zawarte małżeństwo polega na tym: biorę ciebie za żonę, o ile staniesz się chrześcijanką - i wyjaśnia dalej, że jak długo nie nawróci się, małżeństwo między chrześcijaninem a niewierzącą nie może być zawarte ${ }^{41}$.

40 „Magister Ro [landus], etiam cum honesta condicio in contrahendo matrimonio ponitur, dicebat distinguendum circa tempus et factum. Si enim dixerit quispiam: "accipio te in meam, si decem dederis tali die", ex [s] pirat condicio. Si uero dixerit: ,acipiam te in meam si tali die decem dederis". tenent codicio, nisi forte ita de facto processerit, ut ante diem condicionis matrimonium carnis conmixtione perfecerit (f. 139 va)". Joannes Faventinus, C. 28 q. 2 c 1 c. 16 ; Por. Weigand R., dz. cyt., 156

${ }_{41}$ "Cum adicitur conditio matrimonio, restat an talis sit conditio qua existente et non existente possit matrimonium constare, tunc enim spreta conditione stabat matrimonium ut si dicam: "consentio in te, ita tamen ut michi des uel si michi dederis tot in dotem". In hoc casu siue dederit siue non dederit, stabit matrimonium neque hac occasione dimittere possum. Si u e ro talis sit conditio qua non existente matrimonium stare non possit, tunc in pendenti erit obligatio, ut si dixero alicui gentili mulieri: „uolo te habere in uxorem, ita tamen ut fias uel si facta fueris christiana". In hoc casu non erit matrimonium nisi conditio uel modus extiterit, quia inter fidelem et infidelem coniugium ab initio non consistit (f. 27 ra)". - Summa Monacensis ad C. 28 q. 2. Por. Weigand R., dz. cyt., 160 i 168. NB. Podkreślenie moje. 


\section{Symbioza myśli kanoniczno-rzymskiej}

Problem aktu warunkowego zaczyna coraz bardziej dojrzewać, ponieważ w odniesieniu do C. 28 q. 1 c. 16 Szymon z Bisignano wpierw powtarza znaną już teorię, że zaręczyny dokonane pod warunkiem są ważne, ale stają się małżeństwem, jeśli przed dopełnieniem się warunku miało miejsce pożycie fizyczne, w dalszym jednak tekście wspomina równocześnie o innnych autorach, którzy sądzą, że małżeństwo pod warunkiem zawarte staje się waźne dopiero wówczas, kiedy warunek się spełni 42 .

Warto zwrócić uwagę na to stwierdzenie Szymona z Bisignano o innych autorach. Powołują się oni — jego zdaniem - na dekretał C. 2 q. 6 c. 29 , który w odniesieniu do prawa procesowego jest zaczerpnięty z Digestów 49. 4. 1. $5 \mathrm{nn}$. Obserwujemy tutaj ciekawe przeniesienie treści stosowanej przez Rzymian w stosunku do innego rodzaju warunkowych działań prawnych na teren prawa małżeńskiego, gdzie Rzymianie tego warunku nie stosowali. W takim wypadku, zdaniem wspomnianych przez Szymona autorów, uwarunkowane małżeństwo powodowałoby zawieszenie jego ważności do chwili, gdy się spełni warunek. Jak z jednej strony fakt ten jest pośrednim dowodem głębszego studiowania przez kanonistów prawa rzymskiego, tak z drugiej strony dowodzi równocześnie poważniejszego zainteresowania się problemem małżeństw warunkowych. Kanoniści ówcześni świadomi, że małżeństwo zawarte i dopełnione jest ważne i nierozerwalne, na gruncie przygotowanym przez szkołę paryską znajdowali szersze pole zastosowania do małżeństwa elementów prawnorzymskich ${ }^{43}$.

Należy jednak podkreślić, że są to głosy na razie sporadycznie występujące i nie można jeszcze doszukiwać się upowszechnienia tych rozwiązań. Wypowiedzi bowiem innych kanonistów współczesnych świadcza

42 ,Et nota quod secundum quorundam sententiam distinguitur inter tempus et factum; si enim dixerit quis: "uolo te in meam si decem dederis tali die", expirat condicio; si uero dixerit: "accipiam te in meam si tali die decem dederis", tenet condicio, nisi forte ita de facto processerint, ut antequam extaret condiciomatrimonium carnis conmixtione perficiatur. Alii sunt qui dicunt quod, cum matrimonium sub condicione contrahitur, tunc demum matrimonium tenere incipit, cum condicio interposita existit, ut ii q. vi c. Biduum (c. 29) (f. 43 v.)". - Simon de Basignano ad C. 28 q. 1 c. 16 . cyt. Weigand R., dz. cyt., 169. Por. tamże, 170. NB. Podkreślenie moje.

${ }_{43}$,Nach der Lehre "anderer" bewirkt jede Bedingung die Suspension der Ehe; die Ehe wird erst dann gültig, wenn sich die Bedingung erfültt (§ 96). Für ihre Ansicht berufen sich diese Gelehrten auf das cap. Biduum C. 2 q. 6 c. 29 , das eine Übernahme der Digestenstelle 49.4.1.5 ff ist. In ihr wird jedoch nicht von bedingter Eheschliessung geredet, sondern die Frage aufgeworfen, wann nach einer bedingten richterlichen Entscheidung, die an sich unzulässig ist (ein Gerichtsurteil muss sicher sein), die First zur Appellation abläuft; ob dabei vom Ausspruch des bedingten Urteils oder von der Erfüllung der Bedingung an zu rechnen sei, da das Urteil doch erst mit Erfüllung der Bedingung wirksam werde". Weigand R., dz. cyt,, 170. 
o dosyć wielkim niedoprecyzowaniu i zamieszaniu pojęć w tej materii. Swiadczy o tym np. sformułowanie Szymona z Kremony. Zgoda małżeńska - jego zdaniem - powinna być wolna od wszelkiego przymusu, od dodania określenia czasu i jakiegokolwiek warunku. Przyznaje jednak, że niektórzy dopuszczają uwarunkowanie zgody nowożeńców od przyzwolenia np. ich ojca ${ }^{44}$, a w odniesieniu do C. 28 q. 1 stwierdza, że chociaż można zawrzeć zaręczyny pod warunkiem nawrócenia się, jednak samo małżeństwo winno być zawierane bez jakiegokolwiek warunku. Gdyby natomiast faktycznie zawarto małżeństwo pod warunkiem, uważa się ten warunek jako niedołożony ( $\mathrm{n} \mathrm{m}$ etiam apposita non apposita intelligitur, et hoc est privilegium matrimonii" ${ }^{45}$. U tego autora znowu możemy obserwować pomieszanie wpływów teologicznych, typowo kanonicznych i prawa rzymskiego.

\section{Oficjalne potwierdzenia sprzyjają rozwojowi doktryny}

Do dalszego rozwoju myśli kanonicznej w tej materii w dużej mierze przyczynił się Dekretał Aleksandra III, który w swojej odpowiedzi danej arcybiskupowi Palermo, a zamieszczonej w Dekretałach Grzegorza IX: X, 4, 5, 3, pośrednio stwierdza, że nie istnieje obowiązek dochowania zaręczyn, jeżeli druga strona nie wypełnia tego, co w warunku było zastrzeżone, chyba że w międzyczasie zaistniała zgoda aktualna, względnie pożycie fizyczne, co - jak można wnioskować — równałoby się z wycofaniem warunku i zawarciem małżeństwa bezwarunkowego ${ }^{46}$. Od tego czasu ostatnie dwa zastrzeżenia: o ile nie nastąpił consensus de praesenti, albo carnalis comixio, będą się stale powtarzały prawie u wszystkich kanonistów, którzy poruszać będą problem aktu warunkowego. Dekretał zatem Aleksandra III niejako w tym punkcie potwierdził zgodność opinii niektórych kanonistów z doktryną oficjalną i dlatego powszechnie te zastrzeżenia przyjęto. Pierwsza możliwość jest brana pod uwagę do dnia dzisiejszego, a drugą z czasem zaniechano jako opierającą się jedynie na domniemaniu prawnym.

Warto z kolei zwrócić uwagę na Sumę Permissio quaedam. W odniesieniu do C. 28 q. 1 c. 16 ; podaje ona potwierdzenie bardzo lapidarne jak to określa Weigand - że małżeństwo pod warunkiem może być za-

44 Por. Weigand R., dz. cyt., 172.

45 Tamże.

46 ,De illis autem [...] Si vero aliquis sub huiusmodi verbis iuramentum alicui mulieri praestiterit: "Ego te in uxorem accipiam, si tantum mihi donaveris«, re us periurii non habebitur, si eam nolentem sibi solvere, quod i uramento sibi dari petiit, non acceperit in uxorem, nisi consensus de praesenti aut carnalis sit inter eos commixtio subsecuta". X, 4, 5, 3; podkreślenie moje. 
warte ${ }^{47}$. W dalszym natomiast tekście po rozróżnieniu warunków godziwych i niegodziwych, które cytowane są również przez innych autorów, zwraca uwagę na element odnoszący się do warunku omawianego w Sumie Monachijskiej mianowicie: warunek, z którym może istnieć małżeństwo i bez którego nie może ${ }^{48}$. Charakterystyczne dla tego autora jest zwrócenie uwagi na warunek godziwy, który może należéc do istoty kontraktu:, ,est de substantia contractus aut no n". Jednakże słowa, że ,,warunek należy do istoty" również i tutaj należy inaczej rozumieć, aniżeli byśmy dzisiaj te słowa rozumieli, jak to słusznie zauważa Weigand analizując ten tekst. Nawiązuje bowiem do dekretału omawiającego wymaganie nawrócenia do ważności zawieranego małżeństwa. Niemniej warte jest to zasygnalizowania, ponieważ występuje tu rozróżnienie między wymogami godziwości a ważności.

Podobne sformułowanie znajdziemy również w tekście Sumy De iure canonico tractaturus w odniesieniu do C. 28 q. 1 c. 16 . Bardziej jednak charakterystyczna jest glosa znajdująca się na marginesie tego tekstu cytowanego przez Weiganda na str. 191. Rozróżnia ona wa r u n e k, z k tóry m nie może zaistnieć małżeństwo i war un ek, bez którego nie może zaistnieć małżeństwo ${ }^{49}$. Szkoda, że nie ma szerszego rozwinięcia myśli tej glosy.

W dalszym jednak ciągu doktryna o małżeństwie warunkowym nie jest w pełni ustalona, jak świadczą teksty późniejszych kanonistów, którzy, o ile przyjmują ,godziwe" warunki przy zaręczynach, o tyle nie chca się zgodzić na uwarunkowanie samego aktu małżeńskiego. Uważają bowiem, że małżeństwo de praesenti nie przyjmuje warunku, chociażby byl postawiony.

W doktrynie małzeństw warunkowych ważnym momentem jest wydanie Dekretału Urbana III: X. 4, 5, 5. Urban III domaga się w nim pełnej wolności przy zawieraniu małżeństwa w wypadku warunku uzależniającego zgodę od zgody ojca ${ }^{50}$. Stwierdza jednak przy tej okazji, że samo uwarunkowanie jest godziwe, co potwierdzają instytucje kanoniczne. I to jest chyba najważniejsze stwierdzenie pomimo, że autorzy tekst

${ }_{47}^{47}$,Hic colligitur matrimonium sub conditione contrahi posse. (f. 93 va)”. Summa "Permissio quedam", cyt. Weigand R., dz. cyt., 183.

48 ,si fuerit honesta (conditio), aut est de substantia contractus aut non. Si de substantia contractus, ualet ut hic aliter". Tamże, Por. Weigand R., dz. cyt., 183.

${ }_{49}$,Quandoque enim contrahitur sub conditione $\mathrm{cum}$ qua et sine qua potest esse matrimonium, quandoque sub condicione $\mathrm{cum}$ qua $\mathrm{non}$ potest esse matrimonium, quandoque sub conditione sine qua non potest esse matrimonium (f. $158 \mathrm{rb}$ )". - Summa ,De iure Canonico tractaturus ad C. 28 q. 1 c. 16 Glossa, cyt. Weigand R., dz. cyt., 191.

$50, \ldots$ nihilominus respondemus, quod, quum consensus liber dici non possit, qui in alieno arbitrio reservatur, ac conditionem ipsam canonica non improbent instituta, quae consonet honestati, nisi voluntas patris postmodum intercedat, nequaquam cogendus est ad matrimonium contrahendum". X, 4, 5, 5, Por. Weigand R., dz. cyt., 198. 
ten w rozmaity sposób tłumaczą. Jedni uważają, że chodzi tutaj o zatwierdzenie małżeństwa warunkowego w ścisłym tego słowa znaczeniu, inni przyjmują, że zdaniem papieża akt warunkowy zamienia małżeństwo w zaręczyny, które wymagają później nowej zgody de praesenti, gdy warunek się spełni. Faktycznie tekst Urbana III nie jest jednoznaczny i dlatego sprawia autorom dużo trudności. Nic więc dziwnego, że wywołuje rozmaite komentarze np. Huguccio do C 28 q. 1 c. $16{ }^{51}$.

Następni kanoniści zwiększają ilość cytatów zaczerpniętych z prawa rzymskiego, co świadczy o większej jego znajomości. Równocześnie zwiększa się pewne zamieszanie, jeśli chodzi o doprecyzowanie pojęć małżeństwa warunkowego. Niewiele wnosi do naszego zagadnienia Dekretał Innocentego III: $\mathrm{X}, 4,5,6$, który rozstrzyga spór odnośnie małżeństwa zawartego pod warunkiem zgody ojca. Zanim jednak ta zgoda została udzielona, nastąpiło fizyczne pożycie stron, co zdaje się świadczyć o odstąpieniu od warunku. Należy więc domniemywać ważność małżeństwa w takim wypadku ${ }^{52}$. Dekretat potwierdza więc stanowisko zajęte już poprzednio przez kanonistów, pośrednio jednak potwierdza na nowo możliwość zawierania takich związków pod warunkiem.

Powoli jednak dokonuje się przemiana w umysłowości kanonistów. Przykładem tego jest między innymi komentarz Alanus'a do C. 28 q. 1 c. 16, gdzie w pierwszej wersji tego tekstu jest zdecydowanie przeciwny zawieraniu małżeństwa pod warunkiem, natomiast $w$ drugiej czytamy, że małżénstwo, przy zawieraniu którego dołączono warunek, jeszcze nie jest małżństwem, poniewa $\dot{z}$ warunek zawiesza zgodę małżeńską, a bez niej małżeństwo nie może być zawarte ${ }^{53}$. Jest to bardzo znamienna zmiana dokonana pod pośrednim wpływem szkoły paryskiej. O rozwoju doktryny w tym samym kierunku świadczy również aparat glosy: „Militant siquidem patroni", który w odniesieniu do X 4, 5, 5; nie tylko stwierdza niemożność zaistnienia małżeństwa, jeżeli było ono zawarte

51 Por. Weigand R., dz. cyt., 204-217.

52 ,Consultationi tuae taliter respondemus, quod, quum liquido constet per confessionem tam viri quam mulieris, quod post contracta sponsalia carnalis est inter eos copula subsecuta, pro matrimonio est vehementer quidem praesumendum, quia videtur conditione apposita recessisse. Nam etsi probatum sit utrumque per testes, quod, postquam pater et patruus viri contradixere sponsalibus, idem vir mulierem illam carnali commixtione cognovit, non est tamen aliquo modo probatum, quod, antequam ipse cognovisset eandem, pater eius et patrus c ontradicere curavissent'. X, 4. 5. 6. Podkreślenie moje. Por. Weigand R., dz. cyt., 287.

53., ,Secus in matrimonio, in quo si apponatur honesta conditio quecumque, matrimonium non contrahitur, quoniam conditio apposita consensum suspendit sine quo matrimonium non contrahitur, ut supra prox. p. ii $\S i$. Circa conditiones sponsalibus adiectas sic distinguitur: si honesta sit conditio, sponsalia suspenduntur, extra de sponsal. De illis". cyt. Weigand R., dz. cyt., 307. 
pod warunkiem zgody ojca, ale ponadto, że w w yczekiw a ni u na zgodę ojca konsens musi trwać, ponieważ jedynie z goda tworzy małżństwo. Jeżeli jednakzgoda ojca by nie nastąpiła, nie ma również i małżénstwa, ponieważ zgoda zainteresowanych jest uzależiona od jego zgody ${ }^{54}$. A zatem z kontekstu jasno wynika, że w tym wypadku nie tylko chodzi o skuteczność, ale o samo istnienie, o ważność a ktu zawartego pod warunkiem, zgoda bowiem uzależniona jest od spełnienia się warunku. Argumentacja idzie po linii szkoły paryskiej, uznającej wzajemną zgodę za element istotny, tworzący małzeństwo. Jest ona w tym wypadku uzależniona od spełnienia się warunku. Wobec tego nie ma małżeństwa, dopóki warunek się nie spełni. Mamy tu do czynienia z typowym warunkiem zawieszającym. Dlatego truáno się zgodzić z komentarzem do tego tekstu Rudolfa Weiganda, który na końcu swoich rozważań na str. 329 wprowadza określenie rzymskie do swojego komentarza glosy, choć ta była oparta na innych założeniach. Weigand mówi bowiem, że w tym wypadku małżeństwo jest zawarte, ale nieskuteczne. W koncepcji Kościoła nie jest to możliwe nawet, gdy się bierze pod uwagę ujęcie ówczesnych autorów. Małżeństwo bowiem albo jest zawarte i wtedy nie może być uzależnione od przyszłego warunku, albo go jeszcze nie ma, dopóki warunek się nie spełni. Nie można zatem mieszać założeń teoretycznych z innych dziedzin do nauki Kościoła o powstaniu małżeństwa. W nauce Kościoła trudno znaleźć miejsce na małżeństwo istniejące, ale nieskuteczne.

54, ,(1 Comp. 4. 5. 4: X 4.5.5) Quidam contraxit cum quadam sic: »c o $\mathrm{n} t \mathrm{r}$ a h o tecum si pater meus uoluerit«. Dicitur quod non est matrimo$\mathrm{nium}$ nisi patre uolente. In fine determinat contrarietatem que uidebatur inter ipsum et Alexandrem. non prohibent: Hinc dicunt quidam quod quelibet honesta conditio apposita etiam in matrimonio suspendit ut in hoc casu de quo hic agitur, nisi uoluntas patris:: Ergo non est matrimonium nisi uoluntas patris aduenerit. Set nunquid nouus consensus contrahentium post uoluntatem patris exigitur? Videtur quod non, quia ex quo exstat conditio idem est ac si a principio sine conditione consensissent, arg. ...; quod bene concedunt quidam quod ille consensus prohibiuts sufficit et quocumque modo se habeant, adueniente uoluntate patris matrimonium est, nisi interim dissenserint, quia exigitur quod duret consensus. Set obicitur: ille consensus contrahentium aut fuit matrimonialiter aut non. Si fuit matrimonialiter, ergo statim fuit matrimonium, quod est contra decretalem. Si non fuit matrimonialiter nec postea consenserunt matrimonialiter, ergo non dum est matrimonium, quia consensus matrimonium, facit, ut xxvii q. ii $\S$ i. Propter (hoc) dicunt alii quod post uoluntatem patris exigitur nouus consensus contrahentium, aliter non est matrimonium. Posset tamen dici secundum omnes quod per hec uerba: "consentio in te si pater meus uoluerit " contrahitur matrimonium, quod tamen non est nec forte unquam erit, sicut quando episcopus dicit: excommunico te si hoc feceris", ipse reuera excommunicat, non tamen aliquis uinculo exsommunications astringitur. Set quid si ante consensum patris alter fiat furiosus? Nunquam est matrimonium et arg. xxxii q. vii Necque. Est nec similiter matrimonium si interim sit exsectus arg. infra de frigid. et malef. Quod sedem. honestali: Ratio legum est [...]. Nuptie consistere non possunt nisi consentiant omnes, id est qui contrahunt quorumque in potestate sunt, que ratio potest extendi ad personas que emancipationis gaudent benefitio (f. 71 va)". Cyt. Weigand R., dz. cyt., 326 n. NB. Podkreślenie moje. 
W następnych wypowiedziach kanonistów na ten temat ciągle powraca jeszcze przeciwna koncepcja uznająca akt de praesenti z dołaczonym warunkiem jako akt de futuro, wymagający potem nowej zgody. Również i inne poprzednio cytowane koncepcje powracają raz po raz, czemu nie można się dziwić biorąc pod uwagę sposób pracy ówczesnych dekretystów czy dekretalistów. I tak np. Damasus w Broccarda, w komentarzu do pierwszej kompilacji 4, 5, 4 wspomina, że małżeństwo może być zawarte pod warunkiem, ponieważ podlega wszelkim regułom o kontraktach i cytuje cały szereg miejsc z Digestów ${ }^{55}$. Takie właśnie czerpanie materiałów z rozmaitych źródeł o rozmaitych założeniach teoretycznych musiało przeszkadzać w dojściu do jednolitych koncepcji. Jednakże w dalszym tekście komentarza do $\mathrm{X}, 4,4,1$ autor stwierdza, że warunek rozwiązujący w odniesieniu do małżeństwa miejsca mieć nie może, co jest zupełnie słuszne ${ }^{56}$.

Grzegorz IX w Dekretale X, 4, 5, 7 bliżej określa warunek przeciwko istocie małżeństwa i warunki, które uważa się za niedołączone do kontraktu: niemożliwe, względnie niegodziwe. W ten sposób potwierdza oficjalnie dotychczasową doktrynę niektórych kanonistów.

\section{Sprecyzowanie koncepcji kanonicznej}

Najbardziej jasno przedstawiona jest nauka o małżeństwie warunkowym u Innocentego IV ${ }^{57}$. W tekście poniżej cytowanym wyraźnie rozróżniał Innocenty IV warunek niegodziwy od warunku godziwego oraz zaręczyny, czyli sponsalia per promissionem de futuro od aktualnego zawarcia per verba de praesenti. Odnośnie do zaręczyn, tak samo jak i poprzednio twierdzono, przyjmuje, że warunek godziwy zawiesza zaręczyny do czasu jego spełnienia się. Najważniejsze jednak są tutaj słowa dotyczące zawarcia samego małżeństwa. Wy r aźn i e bo wi e m s t wi e rd za, ż ważność małżénstwa jest zawieszona dopóty - chociaż wypowiedziane były słowa, de praesenti", dopóki warunek się nie spełni. Gdyby w mię-

55 Por. tekst cytowany przez Weigand'a R., dz. cyt. 366.

56 Por. tekst cytowany przez Weigand'a R., dz. cyt. 369.

57 ,4. Desponsatio. nam si intervenerunt verba praesentis temporis, puta consentio in te, sicut in uxorem, si feceris furtum, statim est firmum matrimonium, nec suspenditur per conditionem, si vero intervenerunt verba de futuro, statim vera sunt sponsalia nec suspenduntur per conditionem. si vero dixerit, accipio te in uxorem si dederis centum, suspendentur quousque det centum. infra eod. super eod. et si interim contrahat cum alia de praesenti tenet. infra eod. de illis. si vero dixerit contraham, si dederis centum, datis centum non est matrimonium, sed sponsalia, unde si datis centum cum alia contrahat, tenebit matrimonium, similiter si dicat impono tibi annulum, ita quod si dederis centum, fit matrimonium. datis centum matrimonium firmum erit, et eodem modo si dixerit, sint sponsalia nam datis centum erunt sponsalia, Alii contra". Innocentius IV ad $\mathrm{X}, 4,5,1$, (In quinque libros decretalium, Lugduni 1578304 v.). 
dzyczasie, tj. w czasie oczekiwania na spełnienie się warunku zawarł małżeństwo per verba de praesenti z inną osobą, wówczas drugie małżeństwo jest ważne, a nie pierwsze. Jak długo warunek się nie spełnił, pierwsze małżeństwo nie było ważne. Autor podaje dwa różne przykłady, w których wyraźnie rozróżnia małżeństwo warunkowe od zaręczyn warunkowych. W jednym i drugim wypadku chodzi o warunek godziwy, od którego ważność zaręczyn, czy małżeństwa jest uzależniona.

Konsekwentnie zgodne stwierdzenie w porównaniu $\mathrm{z}$ powyżej omawianym rozwiązaniem znajdujemy również w komentarzu Innocentego IV do $\mathrm{X}, 4,5,5$, gdzie rozważając odmienne ujęcia autorów zwraca uwagę co jest istotne dla rozważanego problemu - że w wypadku, gdy zgoda małżeńska była uzależniona od zgody ojca, nie powinni zawierający małżeństwo w międzyczasie odwoływać swojej zgody ,dum modo contradicant". Jeżeliby bowiem to miało miejsce, musi nastąpić nowa zgoda de praesenti 58 .

Zasadniczo po tej samej linii co Innocenty, idzie w odniesieniu do małżeństwa i zaręczyn Henricus de Segusio, cardinalis Ostiensis, w swojej Sumie ks. IV De conditionibus appositis in desponsatione vel aliis contractibus pod nr-em $12^{59}$, gdzie również przyjmuje możliwość zawieszenia ważności zaręczyn względnie małżeństwa, dopóki warunek godziwy i możliwy nie zostanie spełniony. W stosunku do warunków niemożliwych, względnie niegodziwych, przyjmuje tę samą naukę, co większość autorów przed nim. Warto jednak zwrócić uwagę na jego uzasadnienie zamieszczone pod koniec cytowanego numeru. Nawiązuje on tu do argumentacji niektórych kanonistów powołujących się na fakt, że małżeństwo jako actus legitimus nie może być dokonane pod warunkiem. Jego zdaniem nie odnosi się to do małżeństwa, powstającego ze wzajemnej zgody stron, czyli zgodnej woli kontrahentów, która może być zawieszona, czyli uwarunkowana ${ }^{60}$.

58 ,[...] sed dicunt quidam adveniente consensu patris, fieri matrimonium. Consensus enim tunc interveniens signum est consensus de praesenti, dummodo contrarentes ipsum consensum requirant, et idem videtur etiam si ipsum consensum non requirant, dummodo non contradicant, quia si contradicent tunc sine consensu de praesenti non posset contrahi matrimonium, sed si non appareat de conditione praesumitur consensus, quia pro matrimonio est praesumendum. infra. c. prox". Innocentius IV, ad X, 4, 5, 5, tamże p. 305 r.

${ }_{59},[\ldots]$ Si conditio honesta et possibilis apponatur in sponsalibus: ut contraho tecum: vel contraham si dederis mihi centum: vel si pater tuus vel patruus consenserit suspenditur consensus sive sponsalia quosque conditio extet: si tamen post talem consensum conditionalem alius consensus interveniat de praesenti vel carnalis sit copula subsecuta: videtur recessum a conditione: unde statim est matrimonium quamvis conditio extet [...]" Henricus de Segusio, Summa Aurea, IV, de conditionibus appositis in desponsatione vel aliis contractibus $\mathrm{nr} 12$ wyd. Lyon 1537, s. $204 \mathrm{r}$.

$60,[[.$.$] Item actus legitimi non recipiunt conditionem, quare non possunt in$ pendenti esse de iudi. non quemadmodum. aliud in matrimonio quod ex consensu et sola voluntae contrahentium perficitur: et plerumque in pendenti est. supra de sponsal. [...]" tamże. 


\section{ZAKOÑCZENIE}

Biorąc pod uwagę cytowane teksty i powyższe rozważania można stwierdzić, że już w XIII wieku zasadnicze elementy kanonicznego pojęcia warunkowego zawarcia małżeństwa były przynajmniej u poważniejszych autorów sprecyzowane. Nie można jednak wyciągnąć konkluzji, że były już one rozpowszechnione. Dużo jeszcze zamieszania przez długi okres czasu wprowadzało powoływanie się na rozmaite rozwiązania innych autorów, którzy cytując odnośne teksty zaczerpnięte $\mathrm{z}$ prawa rzymskiego, lub fragmentaryczne cytaty nie ujmowali całości doktryny w tej materii. Niewątpliwie proces formowania się kanonicznego pojmowania warunkowego zawarcia małżeństwa przebiegał bardzo powoli i nie w odizolowaniu od współczesnych prądów myślowych. W szczególności zależał on od dyskusji na temat istoty małżeństwa, jaka toczyła się między szkolą paryską a szkołą bolońską. Na ostateczne sformułowanie miało niewątpliwie wpływ zwycięstwo szkoły paryskiej, jeśli chodzi o określenie istotnego elementu przy zawarciu małzeństwa, którym jest zgoda stron. Uwzględniono ponadto pewne uzupełniające elementy zaczerpnięte z prawa rzymskiego o warunku zawieszającym inne kontrakty powstałe na skutek zgody stron.

Były również w Starym Testamencie i w prawie żydowskim odnośne koncepcje, które mogły być źródłem takiej, a nie innej koncepcji aktu warunkowego. Nie ma jednak w źródłach śladów bezpośredniej zaleźności. Nie jest natomiast wykluczona zależność pośrednia ze względu na to, że Stary Testament stale był w użyciu w okresie, kiedy powstawały te pojęcia.

Do takiego a nie innego sformułowania musieli dojść kanoniści również ze względu na strzeżoną od dawna doktrynę o nierozerwalności małżeństwa zawartego i dopełnionego między ochrzczonymi. Nie mogio więc być mowy o warunku rozwiązującym. Dzięki sprecyzowaniu szkoły paryskiej ustalono również, jakie warunki są przeciwne istocie małżeństwa. Nie mogły być one w ogóle brane pod uwagę i traktowano je jako nieistniejące. Tak samo odnoszono się do warunków niegodziwych, chociaż już pod koniec omawianego okresu tu i tam zdarzają się wypadki przyjmujące warunek niegodziwy za wystarczającą przyczynę zawieszenia zgody. Większość jeđnak autorów stoi na stanowisku, że nie bierze się tych warunków pod uwagę. Nie wnikano jednak już głębiej, czy to jest tylko domniemanie zwykłe, czy też kwalifikowane.

Najważniejszym jednak osiągnięciem kanonistów był fakt powolnego wypracowania odrębnej koncepcji zawarcia małżeństwa warunkowego. Nie chodzi więc tutaj o małżeństwo nieskuteczne tak, jak to było przy zawieraniu warunkowych aktów prawnych w prawie rzymskim, lecz 
jedynie istnieje problem: ważność lub nieważność małżeństwa w zależności od spełnienia się lub nie zdarzenia przyszłego i niepewnego. A zatem długa i mozolna droga prowadziła do wypracowania właściwego dla doktryny kanonicznej pojęcia zawierania małżeństwa warunkowego.

\title{
I'ORIGINE DEL CONCETTO CANONICO DEL CONDIZIONATO CONTRATTO DEL MATRIMONIO
}

\author{
Som m a rio
}

Il diritto contemporaneo polacco, come il diritto romano, in linea di massima non prevede la possibilità di contrarre matrimonio sotto condizione. L'atto condizionato viene definito come una riserva delle parti in forza della quale la nascita o.l'estinzione dell'efficacia di un dato atto viene a dipendere dal compiers di una circostanza futura e insicura. Il diritto canonico - prescindendo dai casi di contratti condizionati nelle questioni materiali alle quali, in base al can. 1529, si applicano concetti e norme civili - particolarmente in riferimento al matrimonio contratto sotto condizione, si serve di un concetto un po' diverso: la validità dell'atto giuridico si fa dipendre dall'avverarsi di una circostanza futura e insicura. Non si tratta pertanto unicamente dell'efficacia, ma della validità, cosa comprensibile se si esamina la naura del matrimono. Secondo molti autori i concetti sopra riportati non s'identificano fra di loro, al contrario usandoli uno in sostituzione dcll'altro possono portare a numerose incomprensioni. Pertanto ci si domanda: da quanto tempo a su quali basi si è formato questo diverso concetto canonico?

Già nei libri dell'Antico Testamento troviamo molti esempi del concetto di atto condizionato simile a quello di cui si serve il diritto canonico moderno. Nelle sue fonti, e in particolare in quelle del periodo dei decretisti, non incontriamo richiami egli esempi sopra riportati. Non si puó tuttavia escludere un eventuale influsso indireito pur non essendovi prove. L'influsso del diritto romano sul diritto canonico di quel periodo è tuttavia indubbio e ció non favorisce affatto il formarsi di un concetto proprio e diverso del matrimonio contratto sotto condizione.

Ciononostante già fra i primi decretalisti appare pian piano il concetto e la possibilità di contrarre il fidanzamento - servendoci della lingua moderna - sotto condizione lecita. Come nel diritto romano peró si nega la possibilità di contrarre il matrimonio stesso o di apporre una condizione illecita o impossibile nel momento del fidanzamento. Indubbiamente il modo canonico di concepire la condizione nel contrare matrimonio segui un processo molto lento pur se non isolato dalle correnti intellettuali contemporanee. Importante per tale processo fu l'esito della discussione sugli elementi-essenziali del matrimonio svoltasi nella scuola parigina con a capo Pietro Lombardo e nella scuola bolognese. Le idee elaborate dalla scuola parigina portarono non soltanto a concepire le condizioni contrarie all'essenza del matrimonio, specifiche per i canonisti, ma resero anche possibile applicare alcuni elementi del contratto condizionato secondo il diritto romano al cd. contratto - come si diceva allora - matrimoniale. In tutti e due i casi l'elemento decisivo era costituito dal consenso delle parti. 
E chiaro che nel diritto canonico si poteva parlare soltanto di condizione sospensiva, mai di condizione risolutiva dato che la dottrina parlava dell'indissolubilità del matrimonio contratto e consumato. Il graduale aumento della conoscenza del diritto romano da parte dei canonisti non favoriva un ulteriore sviluppo di una propria concezione del matrimonio condizionato. La conferma ufficiale di alcuni risultati e di alcune soluzioni canoniche data da decretali pontifici aprí nondimeno la strada allo studio del concetto nelle sue singole tappe e al maturare del problema.

Gli elementi fondamentali del concetto canonico di matrimonio contratto sotto condizione vengono precisati dai maggiori autori già nel XIII secolo. Il matrimonio condizionato era già ben concepito nella opera di Innocenzo IV. Nel caso di condizione lecita si ammette la possibilità di contrarre non soltanto il fidanzamento, ma anche il matrimonio. Come dapprima nel fidanzamento l'esistenza di un'obbligazione dipendeva dall' avverarsi di una circostanza futura e insicura, ugualmente Innocenzo IV afferma chiaramente che la validità del matrimonio è sospesa finchè la circostanza futura e insicura non si compia.

La stessa via, per quanto riguarda il matrimonio e il fidanzamento, è seguita da Enrico de Segussia che nella sua Summa ammette la possibilità di sospendere la validità del fidanzamento, nonchè del matrimonio, fino alla realizzazione di una condizione possibile e lecita. La cosa è tanto più singolare dato che nel caso di altri contratti questo stesso autore applica i principii del diritto romano.

Pertanto già nel XIII secolo possiamo trovare fondamenti sufficienti per affermare che i canonisti avevano un concetto diverso del matrimonio contratto sotto condizione; era però la validità del matrimonio contratto, e pertanto la sua esistenza, che si faceva dipendere da una circostanza futura e insicura e non unicamente la sua effica cia, come era inteso dal diritto romano. Tale concetto, anche se non venne subito diffuso, è valido ancora ai nostri giorni. Al suo nascere contribuirono non soltanto le concezioni giuridiche canoniche e romane, ma anche gli correnti intellettuali contemporanei e le discussioni, particolarmente quelle sull'essenza del matrimonio. 